



\section{Effect van verdoven en doden van drachtige dieren op de foetus en vaststellen van de incidentie van doden van (hoog)drachtige dieren in Nederland}

Welzijn van de foetus bij verdoven en slachten van drachtige dieren

M.A. Gerritzen, I.D.E. van Dixhoorn, V.A. Hindle, H.G.M. Reimert

Dit onderzoek is uitgevoerd door Wageningen UR Livestock Research, in opdracht van en gefinancierd door het Ministerie van Economische Zaken, in het kader van het Beleidsondersteunend onderzoek thema

'Dierenwelzijn' (projectnummer BO-20-008-016)

Wageningen UR Livestock Research

Wageningen, augustus 2016

Livestock Research Rapport 963 
M.A. Gerritzen, I.D.E. van Dixhoorn, V.A. Hindle, H.G.M. Reimert, 2016. Effect van verdoven en doden van drachtige dieren op de foetus en vaststellen van de incidentie van doden van (hoog)drachtige dieren in Nederland; Welzijn foetus bij verdoven en slachten van drachtige dieren. Wageningen, Wageningen UR (University \& Research centre) Livestock Research, Livestock Research Rapport 963. Doi: http://dx.doi.org/10.18174/386650

\section{Summary}

Literature shows that unborn fetuses during the last third of gestation, are able to experience pain. It is suggested that suppressive factors cause a decreased level of consciousness during pregnancy in the fetus, and that, depending on species, the newborns become conscious after a few hours to several days or weeks after birth. About this reduced level of consciousness during gestation, opinions differ.

During slaughter and bleeding of the dam fetal oxygen level decreases resulting within a minute result in a flattening of the EEG, which is associated with unconsciousness. It is stated that, when using a proper method of killing, no discomfort can be apparent in the unborn fetus. In addition, it is recommended to leave the embryo within the uterus to prevent breathing and thereby prevent an increasing oxygen level as this would make it conscious. The newborn should then be stunned and killed separately.

There is a large variation in the number of slaughtered pregnant animals within the Netherlands. Pregnancy is not always detected and the duration of pregnancy is difficult to estimate. The uteri are left intact according to current recommendations.

On this basis, we conclude that given current knowledge and general opinion, welfare of the fetus is not at stake. New scientific experimental research should reveal the consciousness level of the fetus during slaughter and killing procedures to subscribe the current point of view.

(C) 2016 Wageningen UR Livestock Research, Postbus 338, $6700 \mathrm{AH}$ Wageningen, T 0317483953 , E info.livestockresearch@wur.nl, www.wageningenUR.nl/livestockresearch. Livestock Research is onderdeel van Wageningen UR (University \& Research centre).

Livestock Research aanvaardt geen aansprakelijkheid voor eventuele schade voortvloeiend uit het gebruik van de resultaten van dit onderzoek of de toepassing van de adviezen.

Alle rechten voorbehouden. Niets uit deze uitgave mag worden vermenigvuldigd en/of openbaar gemaakt worden door middel van druk, fotokopie, microfilm of op welke wijze dan ook zonder voorafgaande toestemming van de uitgever of auteur.

De certificering volgens ISO 9001 door DNV onderstreept ons kwaliteitsniveau. Op als onze onderzoeksopdrachten zijn de Algemene Voorwaarden van de Animal Sciences Group van toepassing. Deze zijn gedeponeerd bij de Arrondissementsrechtbank Zwolle. 


\section{Inhoud}

Samenvatting

Het welzijn en bewustzijn van een ongeboren foetus tijdens het doden van het moederdier 



\section{Samenvatting}

Uit recente wetenschappelijke studies komt naar voren dat het slachten van hoogdrachte dieren vaker voorkomt dan tot nu toe werd gedacht. Als we er van uit gaan dat de foetus in het laatste derde deel van de dracht een perceptie van pijn heeft en ongerief kan ervaren, kan het welzijn van deze groep in het geding zijn. In dit rapport word middels een literatuur studie en een indicatie van de huidige stand van zaken van het slachten van drachtige landbouwhuisdieren in Nederlandse slachthuizen, een inschatting gemaakt van de omvang van dit vraagstuk.

Vanuit onderzoek blijkt dat een ongeboren vrucht fysiologisch en anatomisch in staat is om op pijn prikkels te reageren gedurende het laatste derde deel van de dracht. De discussie of gedurende het slacht of dodingsproces van de moeder de ongeboren vrucht ook daadwerkelijk ongerief kan ervaren, richt zich met name op de vraag of de vrucht zich dit ook daadwerkelijk bewust is. In aanleg en functionaliteit wordt aangenomen dat bewustzijn ook mogelijk is gedurende dit laatste derde deel van de dracht. Door de lage zuurstofspanning gedurende de dracht en andere 'bewustzijn onderdrukkende' factoren, wordt aangenomen dat het bewustzijn niveau laag is bij ongeboren vruchten. Over dit verlaagde bewustzijns niveau gedurende de dracht verschillen de meningen tussen verschillende onderzoekers en deskundigen zoals kraamverzorgers.

Uit onderzoek blijkt dat gedurende het dodingsproces van de moeder, de zuurstof toevoer naar de vrucht wordt belemmerd, wat binnen 1 minuut een afvlakking van het EEG tot gevolg heeft. Deze afvlakking van het EEG wordt normaal gesproken gebruikt om een definitieve staat van onbewust zijn vast te stellen tijdens slachtprocedures. Vanuit dit oogpunt wordt geadviseerd om ongeboren vruchten gedurende het slachtproces in de baarmoeder te laten om ademhaling te voorkomen, waardoor deze onbewust staat aanhoudt, totdat de ongeboren vrucht dood is. Indien de vrucht zou gaan ademhalen, zal de zuurstofspanning weer stijgen en zal er sprake zijn van bewustzijn.

Uit een inventarisatie hoe vaak er drachtige dieren worden geslacht, en hoe daarmee wordt omgegaan blijkt dat er me name toezicht is op dracht gedurende de laatste $10 \%$ van de dracht, aangezien deze dieren dan niet vervoerd mogen worden naar het slachthuis. Baarmoeders worden altijd intact gelaten en het is niet altijd te zien of er sprake was van dracht. Als dit wel wordt geconstateerd, is de duur van de dracht lastig in te schatten. Het intact laten van de baarmoeders is conform de adviezen welke in de literatuur zijn beschreven.

We concluderen dat er in Nederlandse slachthuizen wordt gehandeld conform de huidige adviezen. Gezien de huidige kennis concluderen we dat er geen sprake is van ongerief bij de ongeboren vrucht gedurende het dodings- of slachtproces, mits goed uitgevoerd. Er is op dit moment weinig experimenteel-wetenschappelijke onderbouwing over het bewustzijn van de ongeboren vrucht gedurende het slachtproces. 


\section{$1 \quad$ Inleiding}

Uit recente wetenschappelijke studies komt naar voren dat het slachten van hoogdrachte dieren vaker voorkomt dan tot nu toe werd gedacht (Peisker et.al. 2010, Adama et.al. 2011, Fayemi en Muchenje, 2013.). Daarnaast is er geen eenduidige opvatting over de effecten op de foetus tijdens het verdoven en doden van het moederdier noch over de daarbij behorende risico's en ongerief of hoe snel de dood intreedt bij de ongeboren vrucht (Mellor en Gregory, 2003, Campbell et.al., 2014.). Echter, als we er van uit gaan dat de foetus in het laatste derde deel van de dracht wel degelijk een perceptie van pijn heeft en ongerief kan ervaren, is het duidelijk dat het welzijn van deze groep in het geding kan zijn. Om deze problematiek nader in kaart te brengen en internationaal te agenderen is door Denemarken, Duitsland, Nederland en Zweden een verzoek ingediend bij de EFSA voor een wetenschappelijke opinie naar de dierenwelzijns aspecten bij het verdoven, slachten en doden van drachtige dieren.

Mede als input voor deze EFSA opinie is het gewenst om de Nederlandse situatie in kaart te brengen.

Belangrijke vragen hierbij zijn:

- $\quad$ Op welke wijze worden in Nederland drachtige dieren gedood, zowel voor slacht als om andere redenen en wat zijn de redenen voor het doden van deze drachtige dieren?

- In welk stadium van de dracht worden deze dieren gedood en kunnen we de leeftijd inschatten van de ongeboren gedoodde vruchten (al dan niet de kritische leeftijd van laatste derde deel van de dracht gepasseerd)?

- Volgens welke methoden worden deze dieren (bedwelmd en) gedood?

- $\quad$ Om hoeveel dieren gaat het in Nederland (incidentie) per jaar?

- Hoe wordt omgegaan met de (ongeboren) foetus tijdens het dodings en slacht proces van de moeder, wordt de foetus separaat nog (actief) verdoofd en gedood?

- Wat zou gedaan kunnen worden om het aantal drachtige dieren dat wordt geslacht/gedood te verminderen?

- Wat zou gedaan moeten worden om de foetus te doden, nadat het moederdier is gedood?

Het eerste deel van dit verslag bevat de resulaten van een literatuuronderzoek naar de inschatting van de effecten op de ongeboren vrucht en ervaringen en onderzoeksresultaten uit andere landen. In het tweede deel wordt een indicatie gegeven van de huidige stand van zaken van het slachten van drachtige landbouwhuisdieren in Nederlandse slachthuizen.

In de laatste deel wordt er gerelateerde onderwerpen aanbevolen voor verder onderzoek. Deze zullen meegenomen worden in het formulieren van een voorstel voor uitvoerend onderzoek. Daarbij kijkend naar de mogelijkheden om ongerief (i.e. pijnbeleving en bewustzijn) voor de ongeboren of net geboren dieren vast te stellen op basis van diergerelateerde parameters (gedrag, fysiologie en of endocrinologie). In eerste instantie is dit een concept onderzoeksplan dat een basis zal vormen voor samenwerking met collega wetenschappers in Duitsland en ander betrokken landen (b.v. Denemarken en Zweden). 


\section{$2 \quad$ Het welzijn en bewustzijn van een ongeboren foetus tijdens het doden van het moederdier}

\section{Ongerief en lijden}

Om ongerief of lijden te kunnen ervaren is zowel de mogelijkheid om pijn te kunnen voelen als bewustzijn nodig. Hiervoor moeten de anatomische en fysiologische aanleg aanwezig zijn bij foetussen. De relevantie voor de inschatting van het ongerief van foetussen wordt derhalve bepaald door:

1) In welke ontwikkelingsfase zijn de thalamo-corticale verbindingen tussen sub-corticaal zenuwenstelsel en cerebrale cortex functioneel bij de foetus. Met andere woorden vanaf welk moment kunnen dierlijke foetussen anatomisch en fysiologisch pijn lijden?

2) Is er sprake van bewustzijn bij foetussen en zo ja vanaf welk moment?

Er is overvloedig wetenschappelijk bewijs dat foetussen van zoogdieren op pijnvolle stimuli (kunnen) reageren en er bestaan verschillende methoden om de fysiologische respons op schadelijke of pijnlijke stimuli op de foetus te meten (Anand and Whit Hall 2007, Mellor et.al. 2009, Mellor 2009). Hoewel bekend is dat foetussen reageren op mogelijk pijnlijke stimuli, door vertrekken of terugtrekken van spieren, wordt dit niet als definitief bewijs erkend dat de foetus het zich ook bewust is. De wetenschappelijke discussie richt zich met name op het zich al dan niet bewust zijn van de foetus van de pijn (Mellor and Diesch 2006, Anand and Whit Hall 2007).

Doorgaans wordt lijden met pijn geassocieerd, echter dienen we het lijden breder te trekken naar het ervaren van alle mogelijke vormen van ongerief, wat meer is dan alleen maar pijn (Mellor 2012, Sandoe and Jensen 2013).

In de foetale neurologische ontwikkeling worden drie fasen onderscheiden: Fase 1 waarbij verbindingen tussen sensorisch zenuwen en het ruggenmerg worden aangelegd en een vroege ontwikkeling van gebieden van de hersenen start, fase 2 waarbij verbindingen tussen perifere zenuwen en specifieke loci binnen de hersenen worden aangelegd en fase 3 waarbij sensorische impulsen integraal worden verwerkt waardoor er interactiviteit ontstaat tussen de thalamus en cerebrale cortex.

Vergelijkbaar met de mens, wordt aangenomen dat bij het grootste deel van de zoogdieren pijn perceptie gedurende de laatste trimester van de dracht is ontwikkeld (Noors wetenschappelijk panel voor dierenwelzijn en gezondheid, VKM, 2004). Echter, worden grote verschillen in snelheid van ontwikkeling tussen zoogdiersoorten verwacht.

\section{Bewustzijn}

Leeftijd en rijpheid van de benodigde fysiologische mechanismen van de foetus worden als doorslaggevend beschouwd in het bepalen of een foetus wel of niet bewust kan zijn (Mellor and Gregory, 2003). Bewustzijn van gevoelens is pas mogelijk wanneer er een verbindingen is ontstaan tussen de hersenen en perifere sensibele-receptoren en de hersenen zelf voldoende 'rijp' zijn. Bij schapen zijn de verbindingen tussen receptoren en hersenen op $70 \%$ van de dracht aangelegd. Het wordt als twijfelachtig beschouwd of de hersenen dan voldoende zijn ontwikkeld (Mellor and Gregory, 2003). Toch laten verschillende onderzoekers zien, via metingen van EEG, ECoG (electroencephalogram en electrocorticopram) en electro-oculaire activiteit dat de belangrijkste neurale verbindingen in de hersenen zijn aangelegd op 75-85\% van de dracht bij schapen en andere diersoorten en dat de geïntegreerde cerebrale activiteiten zijn gerijpt (Berger et.al., 1986;Clewlow et.al., 1983; Dawes, 1988; Dawes et.al., 1972; Harding et.al., 1981). Nadat $80 \%$ van de dracht is voltooid bij schaap foetussen wordt een nog verdere ontwikkeling van de cerebrale processen gezien. Indicaties hiervoor zijn een veranderingen in EEG/ECOG activiteit, toename van spierbewegingen, electro-occulaire bewegingen ademhalingsbewegingen en reactie na stimulatie (Clewlow et.al.,1983; Harding et.al., 1981; Rigatto et.al., 1988).

Aan de hand van deze bevindingen suggereren van der Valk et.al. 2004 dat bewustzijn bij foetussen, afhankelijk is van neurale ontwikkeling welke op zijn minst moeten zijn gevorderd tot bovengenoemde fasen en dat er vóór 70\% van de dracht geen sprake kan zijn van bewustzijn.

Ook andere onderzoekers erkennen dat foetussen kunnen lijden op het moment dat de verbindingen tussen de thalamo-corticale en sub-corticale gebieden van de hersenen ontstaan zijn, omdat er dan sprake kan zijn van bewustzijn van een foetus (Mellor et.al. 2005, Mellor and Diesch 2006, 2007, 
2010). Dit corticale bewustzijn wordt gezien als een voorwaarde voor het kunnen lijden. Dit is in lijn met de bevindingen van het "Royal College of Obstetrictians and Gynaecologists" (RCOG, 2010. Koninklijke College van Verloskundigen en Gynaecologen) waarbij ook het foetale vermogen om pijn te kunnen lijden werd beschreven.

Ondanks dat de anatomisch en fysiologische systemen volledig zijn ontwikkeld tijdens de late dracht en vroeg na geboorte, bestaat er controversie over de opvatting of de foetus in staat is om daadwerkelijk pijn te identificeren en te voelen (VKM 2004). Deze stelling wordt onderbouwd door lage zuurstof concentraties in het bloed bij foetussen van lammeren. Deze lage zuurstofconcentratie in het bloed ligt beneden het bewustzijnsniveau van neonaten en volwassenen en derhalve wordt aangenomen dat er geen sprake is van bewustzijn. Echter, het blijft onzeker welk niveau aan bloedzuurstof voldoende is om het bewustzijn te realiseren tijdens de laatste periode van de dracht.

Ook volgens Campbell et.al. (2014), is het vermogen om bewust te zijn geen garantie dat een foetus ook daadwerkelijk bewust is. Als een foetus niet bewust is dan zou het niet kunnen lijden. Volgens Campbell et.al. (2014) is het vaststellen van het welzijn van de foetus tijdens het slachten van het moederdier afhankelijk van wat men verstaat onder "lijden" en of een foetus kan lijden. Het wetenschappelijk debat over het wel of geen pijnlijden van foetussen heeft te maken met in eerste instantie vaststellen of het een corticaal fenomeen is afhankelijk van de cerebraal cortex (Mellor et.al 2005, 2010, Mellor and Diesch 2006, 2007) of misschien sub-corticaal (Merker 2007).

Er zijn mechanismen beschreven die gedurende de dracht tot aan het geboorte het gedrag en het bewustzijn van het foetus onderdrukken. Dit zijn het lage zuurstofgehalte in het foetale bloed, het progesteron (en metabolieten daarvan) gehalte in het foetale bloed, foetale lichaams- en huid temperatuur, en een factor in de placenta, welke placenta-inhibitor wordt genoemd. Het bewustzijn wordt juist geactiveerd door verhoging van het zuurstofniveau in het foetale bloed, oestrogeen niveaus in het foetale bloed, stimuli van koude thermoreceptoren en somato-sensore stimulatie (o.a. ten gevolge van de partus) (Mellor, 2010). Op basis hiervan wordt door verschillende wetenschappers aangenomen dat geen enkele foetus bewust is tot aan de geboorte en dat foetale welzijn per definitie niet in het geding kan zijn, en foetussen geen ongerief kunnen ervaren totdat er sprake is van bewustzijn en dat dit afhankelijk van de species pas optreedt minuten, uren dagen of zelfs maanden na de geboorte en dat daarna wel ongerief kan worden ervaren en het welzijn in het geding kan zijn. Toch kan niet met zekerheid gezegd worden dat een foetus geen bewustzijn ervaart tijdens de dracht (Mellor and Gregory, 2003) en door anderen wordt dan ook het standpunt ingenomen dat foetussen wel bewust zijn voor geboorte en dat derhalve het welzijn aangetast kan zijn.

Er bestaat dus nog steeds een verschil van mening betreffende het bewustzijnsniveau van de foetus (Van der Valk et.al., 2003) en door verschillende auteurs wordt gewezen op de kennishiaten en missende experimenteel wetenschappelijke onderbouwing omtrent deze processen.

\section{Fysiologische processen tijdens het dodingsproces}

Bij herkauwers, wordt tijdens het slachten, nadat het dier is bedwelmd, de nek of borst aangesneden wat een acuut afname in bloedtoename naar de hersenen veroorzaakt. Schapen verliezen ongeveer $50 \%$ van hun bloed tijdens het slachten binnen de eerste 10 seconden na de neksnede (Gregory and Wilkins, 1984, Warriss, 1984). Het hart van de foetus zal na het doden van het moederdier nog langer dan 1 minuut (enkele minuten) blijven kloppen.

Het bloedverlies van het moederdier veroorzaakt ook een acute verstoring van de zuurstofvoorziening richting de foetus (Mellor and Gregory, 2003). Ten gevolge hiervan wordt verondersteld dat er binnen 1 minuut, een afvlakking van de hersenactiviteit (EEG/ECoG activiteit) van de foetus optreedt (overgang naar isoelectrisch). Een vergelijkbare afvlakking van hersenactiviteit is beschreven in onderzoek waarbij de navelstreng van foetale lammeren werd afgeklemd waardoor de zuurstoftoevoer werd belemmerd (Mallard et.al., 1992). Deze afvlakking van EEG was omkeerbaar (de corticale activiteit herstelde) indien de occlusie van de navelstreng maar tijdelijk was (korter dan 5-6 minuten). Wanneer de occlusie langer duurde, ontstond er wel hersenschade (langer dan 10 minuten occlusie, Hunter et.al., 2003). Vergelijkbaar resultaten zijn bij kalveren geconstateerd (Bager et.al., 1992, Gregory and Wotton, 1984, Newhook and Blackmore, 1982). Het optreden van een vlak EEG na 1 minuut is een gemiddelde inschatting op basis van de occlusie van de navelstreng en een inschatting van snelheid van verbloeden. Gedurende het sterven in de baarmoeder worden bewegingen geconstateerd (Mellor and Gregory, 2003). Aangezien deze optreden nadat de zuurstoftoevoer dusdanig is gedaald en er dus een vlak EEG moet zijn, wordt er geconcludeerd dat er geen sprake van bewustzijn is en dat dit onbewuste activiteiten van de foetus zijn, waarbij geen sprake kan zijn van lijden. Echter dit is niet aangetoond op basis van experimenteel onderzoek, maar geconcludeerd vanuit vergelijkbare activiteiten van het lichaam bij volwassen slachtdieren (Gregory, 1998). 
Bij mensen met eenzelfde vlak EEG worden geen klinische symptomen van bewustzijn geconstateerd en deze EEG karakteristieken worden bij dieren gebruikt om een definitieve staat van onbewust zijn vast te stellen tijdens slachtprocedures en bij anesthesie en euthanasie procedures. Op basis hiervan wordt verondersteld dat een foetus geen ongerief kan ervaren op het moment dat het EEG vlak is en dat er maatregelen moeten worden genomen om ervoor te zorgen dat deze ook vlak blijft (Van der Valk et.al. 2004). Er moet voorkomen worden dat de foetus lucht (zuurstof) gaat inademen, waardoor het bloed weer zuurstofrijk zal worden, en er vervolgens EEG activiteit zal optreden, waardoor er wel sprake van bewustzijn zal zijn.

\section{"code of practice"}

Op basis van de huidige kennis wordt aangenomen dat door de zuurstofdaling in het bloed van de foetus gedurende het dodingsproces van de moeder, er geen sprake kan zijn van bewustzijn bij de foetus. Indien het zuurstofniveau zou stijgen, doordat de foetus gaat ademen, zal er wel sprake zijn van bewustzijn. Dit zal dus moeten worden voorkomen. Hierop is het advies gebaseerd om de foetus in de baarmoeder te laten gedurende het slachtproces om zo te voorkomen dat de ademreflex op gang komt. Indien de foetus onverhoopt toch lucht heeft ingeademd, wordt geadviseerd de foetus met een schietmasker te bedwelmen en te doden.

In de UK wetgeving (Home office, 1986, sub-section 3.7) is aangegeven dat het doden van hoog drachtig (laatste trimester) dieren is toegestaan indien gedood volgens een zgn "schedule 1 " methode. $\mathrm{Er}$ is volgens de Britten geen bewijs dat aangeeft dat de dood van het moederdier leidt tot een inhumaan sterfteproces van het ongeboren, zeker als de foetus niet is geraakt of wordt fysiek beschadigd.

Volgens een panel van deskundigen van het Europese Autoriteit voor Voedselveiligheid (EFSA.2004), is het toedienen van een dodelijke injectie van barbituraten de beste optie van doden van drachtige dieren. Hierbij bereikt het dodelijk stof de foetus via de placenta waardoor de dood van moeder en foetus is gegarandeerd. Hetzelfde EFSA-panel maakte wel een pleidooi voor aanvullend onderzoek naar de effecten van het doden van de moederdier aan het welzijn de foetus .

In Nieuw Zeeland, de National Animal Welfare Advisory Committee, (NAWAC, 2010) geeft aan in een review van de "Code of Welfare report" dat een foetus binnen 5 minuten na de neksnede (of neksteek) van de baarmoeder verwijderd moet worden bij het slachten van hoog drachtig dieren. Dit omdat de neksteek een catastrofaal bloedverlies van de baarmoeder veroorzaakt en de toevoer van zuurstof naar de foetus belemmert (Mellor, 2003). De NZ code schrijft voor dat alle levende foetussen uit de baarmoeder moeten worden verwijderd en gedood voordat ze beginnen adem te halen. Dit om het bewustwordingsproces tegen te houden en/of onnodig lijden te vermijden.(Mellor, 2003).

Volgens de SOP van MLA/LiveCorp Australië mogen drachtige dieren niet worden geslacht. Wanneer tijdens het slachten blijkt dat een dier drachtig is, dan moet worden verhinderd dat de foetus gaat ademhalen en bij twijfel moet de foetus worden gedood met een slag tegen het hoofd. (MLA, 2012). De OIE (Office international des Epizoöties; Wereld organisatie diergezondheid; OIE 2008) geeft aan dat, onder normale omstandigheden, dieren in de laatste $10 \%$ van de dracht, niet mogen worden getransporteerd en dus ook niet aangeboden worden voor de slacht. Waar dit wel gebeurt moeten de drachtige dieren apart worden gehuisvest om het welzijn van zowel moederdier als foetus te waarborgen. Hierbij is het advies van de OIE om de foetus niet binnen 5 minuten na het neksneden (of steken) van het moederdier van de placenta te verwijderen. Dit om bewusteloosheid bij de foetus te verzekeren. Dit advies is in tegenspraak met de al eerder genoemde advies van het NAWAC waarbij snelheid van handelen (binnen 5 minuten) is aanbevolen. Wanneer een levensvatbare foetus verwijderd is van de baarmoeder is het zaak om het ademhalen te belemmeren. Overigens, volgens het OIE is het beter om de foetus 15-20 minuten in de baarmoeder te laten. Als er twijfel bestaat over het bewustzijn van de foetus dan kan het gedood worden met een slag tegen het hoofd. Tevens, wordt het afgeraden om de vrucht proberen te redden en in leven te houden vanwege een vermeende verhoogde risico voor het welzijn (zuurstof tekort, hersenbeschadiging en infectie gevaar) van het pasgeboren dier.

Volgens de huidige wetgeving in Nederland, is het verboden hoog drachtige ( $90 \%$ van dracht voltooid) naar een slachthuis te vervoeren. Toch is het incidenteel nodig om drachtige dieren te doden. In respons tot een vraag van het ministerie van landbouw naar advies bij het doden van drachtige dieren, concludeerde De Raad voor Dierenaangelegenheden (RDA, 2003) op basis van wetenschappelijk onderzoek bij schapen, dat er geen sprake kan zijn van een bewustzijn bij de foetus tijdens het slachten van de moederdier. Pas na de eerste ademhalingen na de geboorte is er sprake van 
bewustzijn, volgens de RDA. Tevens was de RDA van mening dat de extrapolatie van resultaten uit wetenschappelijk onderzoek bij schapen naar de situatie bij het rund mogelijk moet zijn.

Verder, volgens de RDA, zijn foetale bewegingen, geobserveerd tijdens het dodingsproces geen bewijs van een bewuste respons van de foetus en dus ook geen indicatie voor eventueel aantasting van het welzijn van de foetus tijdens het dodingsproces. De RDA was derhalve van mening dat de toegepaste methoden voor het doden van drachtige grote landbouwhuisdieren leverde geen onaanvaardbare aantasting van het welzijn van de foetus. Volgens de RDA was het probleem 'esthetische' van aard en handhaving van de toen gebruikelijke praktijken werd aanbevolen. 


\section{Hoe groot is het probleem in Nederland?}

\section{Inventarisatie van de praktijk in Nederland}

Incidentie van slachten van drachtige dieren is in een aantal andere landen gedocumenteerd. Echter gegevens uit Nederland zijn niet voorhanden. Binnen het toezicht door de NVWA valt toezicht op de aanvoer van dieren in de laatste $10 \%$ van de dracht. Bij de toezichthouder is niet bekend hoeveel dieren drachtig, dus vooral binnen $90 \%$ van de drachtperiode worden aangevoerd en geslacht. Om een indruk te krijgen van de incidentie van slachten van drachtige dieren is een belangrijk deel van de Nederlandse roodvlees slachterij telefonisch benaderd.

Van 10 slachterijen of slachterijorganisaties is een respons gekregen over de incidentie van slachten van drachtige dieren (Tabel 1). Duidelijk blijkt dat er een groot verschil is tussen diersoorten en tussen slachterijen maar ook tussen dier categorieën binnen een soort.

\section{Tabel 1}

Incidentie van slachten van drachtige dieren.

\begin{tabular}{lllll} 
& Bovine & pigs & horses & Sheep / goat \\
Slaughterhouse $(\mathrm{n})$ & 5 & 2 & 1 & 6 \\
\hline Average $(\%)$ & 0.75 & 0.5 & 1 & 15.2 \\
\hline Range $(\%)$ & $0.3-2.5$ & $0-1$ & 1 & $0-50$ \\
\hline
\end{tabular}

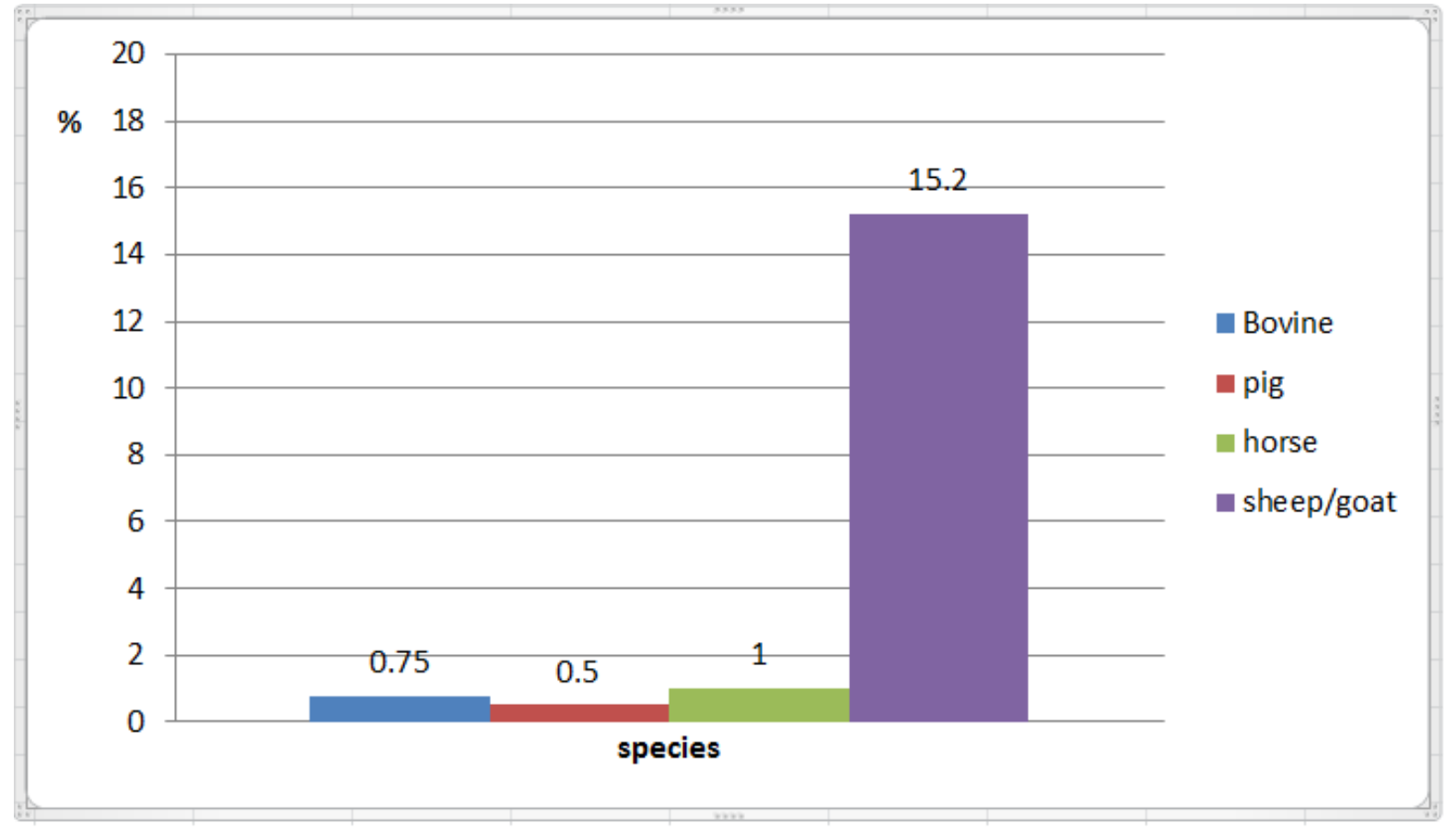

Figuur 1. Gemiddeld percentage drachtig geslachte dieren per soort. 
De respons van de verschillende slachterij organisaties was zeer divers en is hieronder geanonimiseerd weergegeven.

1. Schapenslachterij: Er worden geen gegevens bijgehouden maar naar schatting wordt $25 \%$ van de schapen drachtig aangevoerd. Er is geen protocol hoe om te gaan er met de foetus. Praktijk is dat de ongeopende baarmoeder de destructie bak ingaat. Het duurt tot wel een half uur voordat de baarmoeder wordt verwijderd. Aanname van slachterij is dat foetus dood is doordat er geen bloedtoevoer meer is. Een enkele keer wordt er een lam in de wachtruimte geboren.

2. Schapenslachterij: $\mathrm{Er}$ is een onderscheid tussen jonge ooien en oude schapen. Jonge ooien geschat percentage van $12 / 13 \%$ bij oude schapen wel tot $50 \%$ van de dieren drachtig aangevoerd. Er is geen protocol, foetus wordt met ongeopende baarmoeder in destructiebak gedaan. Aanname dat ongeboren lam niet meer leeft omdat bloedtoevoer is afgesneden.

3. Slachterij organisatie varken en rund: bij runderen op 1 slachterij ca $0.5 \%$ van de dieren in laatste $30 \%$ van de dracht. Jonge dier wordt verbloed. Meestal gaat ongeboren vrucht met gesloten baarmoeder naar destructie.

$\mathrm{Bij}$ varkens komen drachtig aangevoerde dieren niet of nauwelijks voor, tenminste niet in een stadium waarin dit wordt opgemerkt.

4. Varkensslachterij: Vleesvarkens geen drachtige dieren. Bij zeugen komt drachtige aanvoer eigenlijk niet voor behalve bij een calamiteit. Bij geiten komt drachtige aanvoer heel incidenteel voor of bij een calamiteit. Er is geen protocol, baarmoeder gaat ongeopend naar destructie.

5. Slachterij diverse diersoorten: slacht 5 a 6 runderen per week. Ca 4 keer per jaar drachtig dier aangevoerd / geslacht. Foetus is dan $15-20 \mathrm{~cm}$. Bloedtoevoer is afgesneden dus foetus is dood en wordt afgevoerd naar destructie. Bij geiten komt drachtige aanvoer niet voor. Bij schapen komt drachtige aanvoer komt niet voor

6. Slachterij diverse diersoorten: Bij zeugen komt drachtige aanvoer niet voor, bij runderen incidenteel, bij paarden $1 \%$ en bij schapen $2 \%$. Bloedtoevoer is afgesneden en het duurt wel een halfuur voordat buikinhoud wordt verwijderd. Baarmoeder met foetus gaat naar destructie.

7. Runderslachterij: wil geen antwoord geven ivm gevoeligheid van informatie.

8. Herkauwer slachterij: runderen worden heel incidenteel drachtige aangevoerd ca 1 per 3 weken. Bij schapen wisselend, varieert van 0-10\%. Er is geen protocol, de foetus is dood en gaat naar destructie

9. Runder- en schapenslachterij: van de aangevoerde runderen 2,5\% drachtig aangevoerd (ca 25 per maand). Van de schapen wordt ca 4,5\% drachtig aangevoerd. Er is geen protocol, "bloedtoevoer is afgesneden dus zijn dood".

10. Runderslachterij: heel wisselend hoeveel drachtige dieren worden aangevoerd, varieert van enkele per week tot weken helemaal niet. Protocol; als het aan de buitenkant is te zien dat een dier drachtig is neemt de toezichthoudend dierenarts het over en deze neemt de beslissing wat te doen. Als het niet aan de buitenkant is te zien gaat baarmoeder naar destructie. 


\section{$4 \quad$ Conclusie en aanbeveling}

Uit literatuur blijkt dat ongeboren vruchten gedurende het laatste derde deel van de dracht, in staat zijn om pijn te ervaren. Er wordt aangenomen dat er bewustzijns onderdrukkende factoren zijn die ervoor zorgen dat ongeboren vruchten een verlaagd bewustzijns niveau hebben en dat afhankelijk van diersoort er pas sprake is van bewustzijn enkele uren na, tot enkele dagen of weken na de geboorte. Over dit verlaagde bewustzijnsniveau gedurende de dracht verschillen de meningen.

Tijdens het slachtproces en verbloeden van het moederdier daalt de zuurstofspanning in de vrucht wat binnen een minuut een afvlakking van het EEG tot gevolg heeft, welke wordt geassocieerd met onbewustzijn. Op basis hiervan wordt gesteld dat, bij een juiste dodingsmethode, er geen sprake van ongerief is bij de vrucht. Daarbij wordt geadviseerd om de vrucht in de baarmoeder te laten om ademhaling en daarmee een weer stijgende zuurstofspanning te voorkomen. Er zou dan namelijk wel sprake zijn van bewustzijn en het dier zal dan apart gedood moeten worden (b.v. met schietmasker en verbloeden).

Vanuit de praktijk blijkt dat er een grote variatie is in het aantal geslachte drachtige dieren. Over het algemeen wordt een dracht niet altijd geconstateerd en de duur van de dracht is lastig in te schatten. De baarmoeders worden in tact gelaten conform de huidige adviezen.

Op basis hiervan concluderen we dat gezien de huidige kennis en algemene opvatting, er waarschijnlijk geen sprake is van ongerief voor de ongeboren vrucht. 


\section{$5 \quad$ Literatuur}

Adama, J.Y., E. L. Shiawoya and N. Michael. 2011. Incidence of foetal wastages of cows slaughtered in Minna abattoir, Niger state, Nigeria. J. Appl. Biosci. 42: 2876-2881.

Abdulkadir, U., E.Z. Jiya and S.A. Kosu 2008. Survey of Foetal Wastages: A Case Study of Makurdi Abattoir in Benue State from 1997 to 2002. Pakistan Journal of Nutrition 7 (3): 450-452.

K.J.S. Anand, MBBS, DPhil R. Whit Hall, MD. 2007. Controversies in Neonatal Pain: An Introduction, Seminars in Perinatology; Volume 31, Issue 5, October 2007, Pages 273-274

Bager, F., Braggins, T.J., Devine, C.E., Graafhuis, A.E., Mellor, D.J., Tavener, A., Upsdell, M.P., 1992. Onset of insensibility at slaughter in calves: effects of electroplectic seizure and exsanguination on spontaneous electrocortical activity and indices of cerebral metabolism. Research in Veterinary Science 52, 162-173.

Berger, P.J., Walker, A.M., Horne, R., Brodecky, V., Wilkinson, M.H., Wilson, F., Maloney, J.E., 1986. Phasic respiratory activity in the fetal lamb during late gestation and labour. Respiration Physiology $65,55-68$.

Campbell, M.L.H., D.J. Mellor and P. Sandøe. 2014. How should the welfare of fetal and neurologically immature postnatal animals be protected? Animal Welfare, 23: 369-379.

Clewlow, F., Dawes, G.S., Johnston, B.M., Walker, D.W., 1983. Changes in breathing, electrocortical and muscle activity in unanaesthetized fetal lambs with age. Journal of Physiology 341, 463-476.

Dawes, G.S., 1988. The 1987 James AF. Stevenson memorial lecture. The development of fetal behavioural patterns. Canadian Journal of Physiology and Pharmacology 66, 541-548.

Dawes, G.S., Fox, H.E., Leduc, B.M., Liggins, G.C., Richards, R.T.,1972. Respiratory movements and rapid eye movement sleep in the foetal lamb. Journal of Physiology 220, 119-143.

EFSA, 2004. Welfare aspects of the main systems of stunning and killing the main commercial species of animals. EFSA Journal 45, 1-29.

Fayemi, P.O. and V. Muchenje 2013. Maternal slaughter at abattoirs: history, causes, cases and the meat industry. SpringerPlus 2013, 2:125.

Gregory, N.G., Wotton, S.B., 1984. Sheep slaughtering procedures. II. Time to loss of brain responsiveness after exsanguination or cardiac arrest. British Veterinary Journal 140, 354-360.

Harding, R., Poore, E.R., Cohen, G.L., 1981. The effect of brief episodes of diminished uterine blood flow on breathing movements, sleep states and heart rate in fetal sheep. Journal of Developmental Physiology 3, 231-243.

Home office, 1986. Code of Practice for the Humane Killing of Animals under Schedule 1 to the Animals(Scientific Procedures) Act 1986. www.homeoffice.gov.uk

Christian J. Hunter, PhD; Laura Bennet, PhD; Gordon G. Power, PhD; Vincent Roelfsema, BS; Arlin B. Blood, PhD; Josine S. Quaedackers, BS; Sherly George, PhD; Jian Guan, PhD; Alistair J. Gunn, MBChB, PhD. 2003. Key Neuroprotective Role for Endogenous Adenosine A1 Receptor Activation During Asphyxia in the Fetal Sheep. Stroke 34: 2240-2245

MLA, 2012. Standard operating procedures for welfare of cattle in overseas markets. Meat and Livestock Australia Ltd and LiveCorp. Sydney Australia.. pp 66.

Mallard, E.C., Gunn, A.J., Williams, C.E., Johnston, B.M., Gluckman, P.D., 1992. Transient umbilical cord occlusion causes hippocampal damage in the fetal sheep. American Journal of Obstetrics and Gynecology 167, 1423-1430.

Mellor, D.J. 2003. Guidelines for the humane slaughter of the foetuses of pregnant ruminants. Surveillance 30: 26-28.

Mellor, D.J. 2012. Animal emotions, behaviour and the promotion of positive welfare states. N.Z. Vet. J. 60: $1-8$. 
Mellor, D. J. 2013. Production animals: ethical and welfare issues raised by production-focused management of newborn livestock. In: Wathes CM, Corr SA, May SA, McCulloch SP and Whiting MC (eds) Veterinary and Animal Ethics: proceedings of the first International Conference on Veterinary and Animal Ethics pp 174-187. September 2011, London, UK.

Mellor, D.J. and N.G. Gregory 2003. Responsiveness, behavioural arousal and awareness in fetal and newborn lambs: experimental, practical and therapeutic implications, New Zealand Veterinary Journal, 51:1, 2-13.

Mellor, D.J., E. Patterson-Kane and K.J. Stafford. 2009. The Sciences of Animal welfare. WileyBlackwell: Oxford, UK.

Mellor, D.J., T.J. Diesch and C.B. Johnson. 2010. Should mammalian foetuses be excluded from regulations protecting animals during exerients? Alternatives to Animal Experimentation 27: 199201.

Mellor, Professor David J, Galloping colts, fetal feelings and reassuring regulations -Putting animal welfare science into practice, Animal Welfare Science and Bioethics Centre, Massey University, Palmerston North, New Zealand. J Vet Med Educ. 2010 Spring;37(1):94-100. doi:0.3138/jvme.37.1.94.

Merker, B. 2007. Consciousness without a cerebral cortex: a challenge for neuroscience and medicine. Behavioural and Brain Sciences 30: 63-81.

Morreall, J. 1991. Cuteness. Brit. J. of Asthetics 31: 39-47.

Morris, P.H., V. Reddy and R.C. Bunting. 1995. The survival of the cutest: who's responsible for the evolution of the teddy bear? Ani. Behav. 50: 1697-1700.

NAWAC, 2010. Animal Welfare (Commercial slaughter) Code of Welfare Report. Pp28.

Newhook, J.C., Blackmore, D.K., 1982. Electroencephalographic studies of stunning and slaughter of sheep and calves. Part 2. Meat Science 6, 295-300.

Peisker N., A.K. Preissel, H.D. Reichenbach, T. Schuster and J. Henke. 2010. Foetal stress responses to euthanasia of pregnant sheep. Berliner und Münchener Tierärztliche Wochenschrift 123: 2-10.

RDA, 2003. Het doden van drachtige grote landbouwhuisdieren. Raad voor Dieraangelegenheden.

Rigatto, H., Lee, D., Davi, M., Moore, M., Rigatto, E., Cates, D.,1988. Effect of increased arterial CO2 on fetal breathing and behaviour in sheep. Journal of Applied Physiology 64, 982-987.

Rutherford, K.M.D.,G. Arnott, and J. A. Rooke. 2014. Mothers matter: How management of animals during pregnancy affects their progeny. Veterinary Ireland Journal Volume 4 Number 10, 532-535.

Sandøe $\mathrm{P}$ and K.K. Jensen. 2013. The idea of animal welfare: developments and tensiona. In: Wathes CM, Corr SA, May SA, McCulloch SP and Whiting MC (eds) Veterinary and Animal Ethics: proceedings of the first International Conference on Veterinary and Animal Ethics pp 1-9. September 2011, Oxford, UK.

Van der Valk, J., D. Mellor, R. Brands, R. Fischer, F. Gruber, G. Gstraunthaler, L. Hellebrekers, J. Hyllner, F.H. Jonker, P. Prieto, M. Thalen and V. Baumans. 2004. The humane collection of fetal bovine serum and possibilities for serum-free cell and tissue culture. Toxicology in Vitro 18 (2004) $1-12$

VKM, 2004. Opinion of the Scientific Panel on Animal Health and Welfare of the Norwegian Scientific Committee for Food Safety related to the ability of the foetus to sense or feel discomfort, pain and stress. http://vkm.no/dav/9b444f9f25.pdf

Warriss, P.D., 1984. Exsanguination of animals at slaughter and the residual blood content of meat. Veterinary Record 115, 292-295. 
Whitlock, B.K. and H. S. Maxwell. 2008. Pregnancy-associated glycoproteins and pregnancy wastage in cattle. Theriogenology 70 (2008) 550-559 

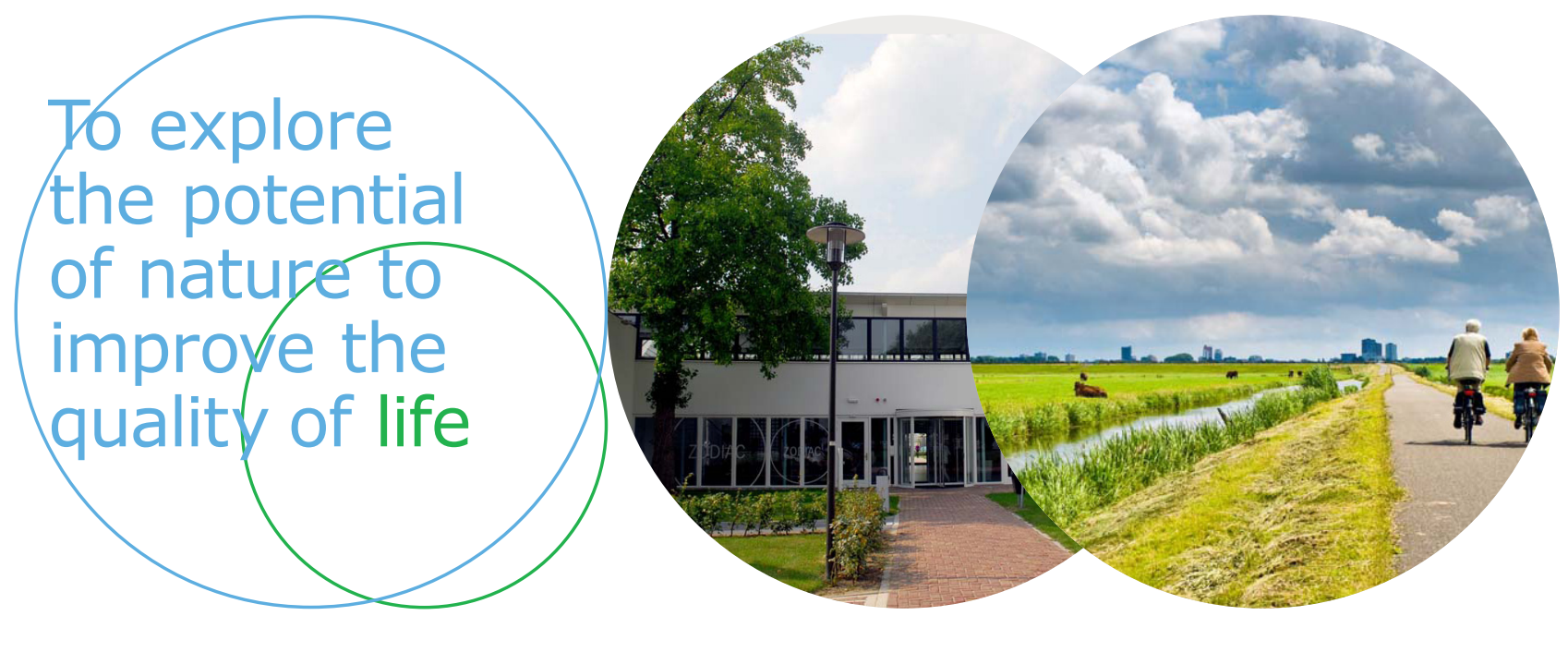

Wageningen UR Livestock Research Postbus 338

$6700 \mathrm{AH}$ Wageningen

T 0317483953

E info.livestockresearch@wur.nl

www.wageningenUR.nl/livestockresearch
Wageningen UR Livestock Research ontwikkelt kennis voor een zorgvuldige en renderende veehouderij, vertaalt deze naar praktijkgerichte oplossingen en innovaties, en zorgt voor doorstroming van deze kennis. Onze wetenschappelijke kennis op het gebied van veehouderijsystemen en van voeding, genetica, welzijn en milieu-impact van landbouwhuisdieren integreren we, samen met onze klanten, tot veehouderijconcepten voor de $21 \mathrm{e}$ eeuw.

De missie van Wageningen UR (University \& Research centre) is 'To explore the potential of nature to improve the quality of life'. Binnen Wageningen UR bundelen 9 gespecialiseerde onderzoeksinstituten van stichting DLO en Wageningen University hun krachten om bij te dragen aan de oplossing van belangrijke vragen in het domein van gezonde voeding en leefomgeving. Met ongeveer 30 vestigingen, 6.000 medewerkers en 10.000 studenten behoort Wageningen UR wereldwijd tot de aansprekende kennisinstellingen binnen haar domein. De integrale benadering van de vraagstukken en de samenwerking tussen verschillende disciplines vormen het hart van de unieke Wageningen aanpak. 